\title{
Not so wide face: The first root-eating beetle of the genus Europs (Coleoptera: Monotomidae) in Mexican amber
}

\author{
J. Kupryjanowicz', G.Yu. Lyubarsky², E.E. Perkovsky ${ }^{3,4}$
}

\author{
${ }^{1}$ Andrzej Myrcha's University Center of Natural Sciences, University of Bialystok, Biatystok, 15- \\ 089 Poland. E-mail: kuprzool@uwb.edu.pl \\ ${ }^{2}$ Zoological Museum, Moscow State University, ul. Bol'shaya Nikitskaya 2, Moscow, 125009 \\ Russia.E-mail: lgeorgy@rambler.ru \\ ${ }^{3}$ Schmalhausen Institute of Zoology, National Academy of Sciences of Ukraine, ul. Bogdana \\ Khmel'nitskogo 15, Kiev,01030 Ukraine.E-mail: perkovsk@gmail.com \\ ${ }^{4}$ A.A. Borissiak Paleontological Institute, Russian Academy of Sciences, Profsoyuznaya 123, \\ Moscow, 117868 Russia.
}

ABSTRACT. Europs makarovi sp.n. is described from Mexican amber (Chiapas, Simojovel). This new species seems similar to the extant E. cognatus Sharp, 1900 and E. sulcicollis Bousquet, 2003, but differs from them because of the relatively longer head, and much stronger puncturation of the head and pronotum. The new species of Europs is distinguished from all contemporary species of the genus by a combination of features: uniformly dark body colour; relatively long head (the ratio of head length to length of pronotum is 0.76 ); very coarse head puncturation; disc of pronotum with 2 longitudinal, more or less parallel, punctate grooves, forming a lyre figure; a wide impunctate medial area between grooves (as wide as diameters of 7-8 punctures); not rounded but triangularly produced coxal line in the first ventrite; proportionally longer elytra (LE/LP > 1.98).

How to cite this article: Kupryjanowicz J., Lyubarsky G.Yu., Perkovsky E.E. 2020. Not so wide face: The first root-eating beetle of the genus Europs (Coleoptera: Monotomidae) in Mexican amber // Invert. Zool. Vol.17. No.2. P.145-153. doi: 10.15298/invertzool.17.2.04

KEY WORDS: Coleoptera, Monotomidae, Europs, Miocene, Mexican amber.

\section{Не слишком широкое лицо: первый вид жуков рода Europs (Coleoptera: Monotomidae) из мексиканского янтаря}

\author{
Я. Куприянович ${ }^{1}$, Г.Ю. Любарский², Е.Э. Перковский ${ }^{3,4}$ \\ ${ }^{1}$ Andrzej Myrcha's University Center of Natural Sciences, University of Biatystok, Białystok, 15- \\ 089 Poland.E-mail: kuprzool@uwb.edu.pl \\ ${ }^{2}$ НИ Зоологический музей МГУ, Большая Никитская 2, Москва 103009 Pоссия. E-mail: \\ lgeorgy@rambler.ru \\ ${ }^{3}$ Институт зоологии им. И.И. Шмальгаузена НАН Украины, ул. Б. Хмельницкого, 15, Киев, \\ 01030, Украина. E-mail::perkovsk@gmail.com \\ ${ }^{4}$ Палеонтологический институт им. А.А. Борисяка РАН, Профсоюзная ул. 123, Москва \\ 117997, Россия.
}

РЕЗЮМЕ. Из мексиканского янтаря (Чьяпас, Симоховель) описан новый вид монотомид Europs makarovi sp.n. Новый вид похож на современные виды E. cognatus Sharp, 1900 и E. sulcicollis Bousquet, 2003, отличается от них менее поперечной 
головой, сильнее пунктированным голове и переднеспинке. Новый вид отличается от всех современных видов рода по следующей совокупности признаков: тело одноцветно-темное; голова относительно длинная (отношение длины головы к длине переднеспинки 0,76); голова и переднеспинка очень сильно пунктированы; диск переднеспинки с двумя параллельными сильно пунктированными бороздами, образующими лировидную фигуру; непунктированная область внутри этой фигуры широкая (ее ширина составляет 7-8 диаметров точки); бедренные линии на первом сегменте брюшка образуют треугольник, не округлены; надкрылья пропорционально длиннее (LE/LP > 1,98).

Как цитировать эту статью: Kupryjanowicz J., Lyubarsky G.Yu., Perkovsky E.E. 2020. Not so wide face: The first root-eating beetle of the genus Europs (Coleoptera: Monotomidae) in Mexican amber// Invert.Zool. Vol.17. No.2.P.145-153. doi: 10.15298/invertzool.17.2.04

КЛЮЧЕВЫЕ СЛОВА: Coleoptera, Monotomidae, Europs, миоцен, мексиканский янтарь.

\section{Introduction}

Root-eating beetles (Monotomidae Laporte, 1840) comprise a family of predaceous or mycophagous cucujoid beetles, distributed worldwide. The family includes 36 genera with about 250 described species (Bousquet, 2010). The Monotomidae is divided into three subfamilies: Rhizophaginae Redtenbacher, 1845, Monotominae Laporte, 1840 (Sen Gupta, 1988), and $\dagger$ Rhizophtominae Kirejtshuk et Azar, 2009. The family consists of seven tribes: Rhizophagini (Rhizophagus), Lenacini (Lenax), Monotomini (Monotoma), Thionini (Thione, Shoguna, Arunus), †Rhizophtomini (†Rhizophtoma, $\uparrow$ Rhizobactron), $\uparrow$ Cretakarennini (†Cretakarenni), and Europini for the remaining genera (detailed view in Liu et al., 2020). The middle Jurassic genus $\dagger J u$ rorhizophagus Cai et al., 2015 has not been assigned to either of the subfamilies.

Several genera of Mesozoic monotomids were recently described. Kirejtshuk et al. (2009) and Kirejtshuk \& Azar (2013) described the fossil genera Rhizophtoma and Rhizobactron Kirejtshuk, 2013 from Barremian Lebanese amber (11-segment antennae, with a two- or three-segment club; pronotum subquadrangular; procoxal cavities distinctly transverse; diffusely punctate elytra). Jurorhizophagus alienus was described from Middle Jurassic Dao- hugou beds (ca165 Ma), Inner Mongolia, northeastern China. This represents the earliest fossil Monotomidae known to date (Cai et al., 2015). Peris \& Delclos (2015) described another species of Rhizophtoma and a new genus, Cretakarenni, with two species within the same subfamily from late Albian Spanish amber and the earliest Cenomanian Burmese amber (Jiang et al., 2019). The oldest Monotominae (Lenacini) Lenax karenae; Cretolenax carinatus, and C. diabolus are described from the earliest Cenomanian Burmese amber (Liu et al., 2020).

From Baltic amber was described the oldest Europini Europs insterburgensis Alexeev (Alexeev, 2014), and Aneurops daugpilensis (Bukejs, Alexeev, 2015). Monotomids were also recorded in Rovno amber (Perkovsky et al., 2010), but still not found in Oise amber (Kirejtshuk, Nel, 2013).

Recently, a beetle belonging to this genus was found in Miocene Mexican amber. The specimen was classified to Monotomidae because of the following morphological features: (1) generally narrow-elongate body; (2) head prognathous, with lateral faceted eyes; (3) fronto-clypeal suture absent; (4) antennal insertions lateral and partly hidden; (5) short, 10-segment antennae (antennomeres X and XI fused) with a distinct two-segment club; (6) procoxae rounded with hidden trochantins; (7) procoxal cavities broadly closed externally; (8) tarsal formula 
$4-4-4,5-5-5$, or a combination of those; (9) elytra exposing one or two abdominal segments; and (10) abdomen with five ventrites: ventrites I and V elongated; ventrites II-IV comparatively short, subequal (SenGupta 1988; Bousquet, 2010; McElrath et al., 2012; Peris, Delclòs, 2015).

Earlier in the Mexican amber there were no monotomid records (Solórzano-Kraemer, 2010). In the current paper a new species of Monotomidae, from Miocene Mexican amber, assigned to the extant genus Europs Wollaston, 1854 , is described, illustrated and compared with extant species from the USA, Mexico and Guatemala.

The specimen belongs to Europs because of the following morphological features: head without antennal grooves, antenna with a 2segment club, pronotal disc with impunctate medial zone, fore coxae rounded, elytral disc with setigerous punctures arranged in longitudinal rows; elytra with rows of punctures, inflexed part of elytron with 3 rows of punctures, first visible abdominal sternite of male without medial plaque bearing proportionally long setae (Sen Gupta, 1988; Bousquet, 2003; Alexeev, 2014).

Species of Europs are found under the bark of dead trees or are associated with cultivated plants; and possibly feed on spores of ascomycetes. They are attracted to black light and probably also to rotting fruits (Bousquet, 2003). Jenkins et al. (2013, 2015) established Europs fervidus Blatchley, 1928 as an important pollinator of atemoya (Annonaceae) (a hybrid of two species of Annona plants).

Families such as Monotomidae, Silvanidae and Prosotomidae which have a flat body show a clear adaptation and a strong relation with the subcortical arboreal environment (Peris et al., 2016). The thermophile genus Europs Wollaston, 1854 includes more than 50 species that have been described from south of North America, South America, the Oriental region, and Africa, including Madagascar. The Nearctic species of the genus were revised in 2003 (Bousquet, 2003); only one species is found in temperate regions; in the continental Western
Palearctic the genus is absent. In the Palaearctic region (Jelínek, 2007) E. temporis Reitter, 1884 was reported from Japan and the Far East of Russia, E. duplicatus Wollaston, 1862 from the Canary Islands; E. impressicollis Wollaston, 1854 from the Canary Islands and Madeira, E. indicus Grouvelle, 1903 and E. alutaceus Champion, 1924 from India. Extant representatives of the genus are not well understood. It is noted that species discrimination is difficult using the existing literature.

\section{Material and Methods}

The beetle inclusion is preserved in a polished piece of amber, yellowish in colour, without supplementary fixation. The amber piece is elongate $(11 \times 10 \times 4 \mathrm{~mm})$ and was obtained from a commercial source in Amberif 2015 (Gdańsk, Poland). It has been polished by hand, thus allowing dorsal and lateral views of the included beetle. Additional inclusions of obvious animal origins are represented by: two Acarina, one female of Coccinea (?Matsucoccidae) and two damaged leaf fragments (probably Mimosa and Hymenea). The amber piece with the inclusions is deposited in the J. Kupryjanowicz collection at the Andrzej Myrcha Centre of Nature, University of Białystok, Poland (UCP UwB). The type will be deposited in the UCP UwB for permanent preservation.

Photographs were taken in the Laboratory of Evolutionary Biology and Insect Ecology at the Faculty of Biology, University of Białystok. Photographs were taken with an Olympus DSX110 stereomicroscope and a camera with a colour CCD image sensor (1/1.8 inch, 2.01 megapixels), equipped with a DSXPLFL $3.6 \mathrm{x}$ lens.

The following measurements were taken using an ocular micrometer in a stereoscopic microscope: maximum width of the head, including eyes (WH); maximum width of the pronotum, excluding the anterior angles (WP); length of the pronotum along the midline (LP); length of elytra from the posterior extremity of the scutellum to the tip of the right elytron (LE). 

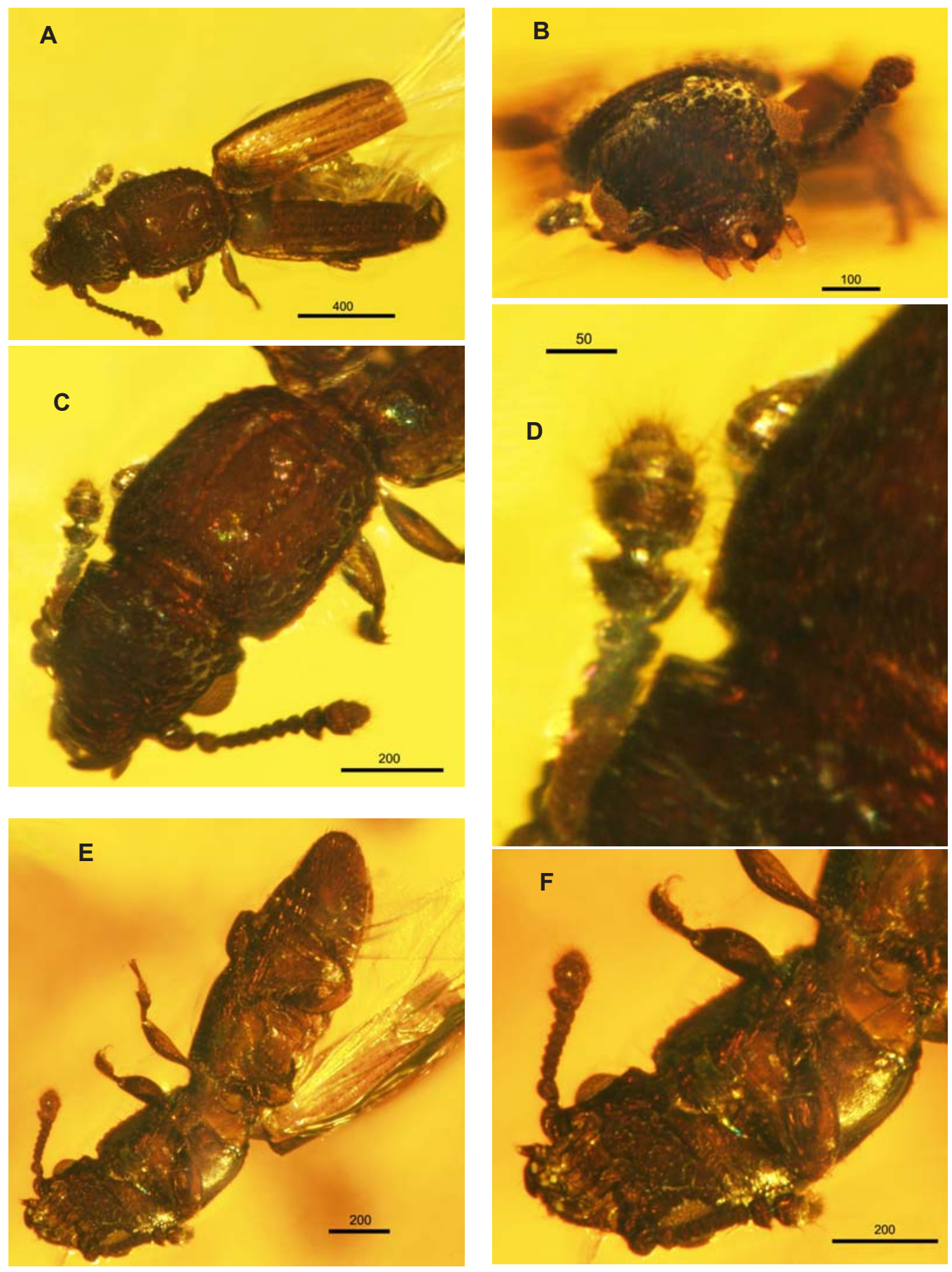

Fig. 1. Europs makarovi sp.n. (photo, scales in $\mu \mathrm{m}$ ).

A - total view, dorsal; B - head, in front; $\mathrm{C}$ - head and pronotum, dorsal; D - antenna, ventral; $\mathrm{E}$ - total view, ventral; F - head and prothorax, ventral; G - pro-, meso- and metathorax, ventral; H - mesotarsus; I - abdomen, ventral. 

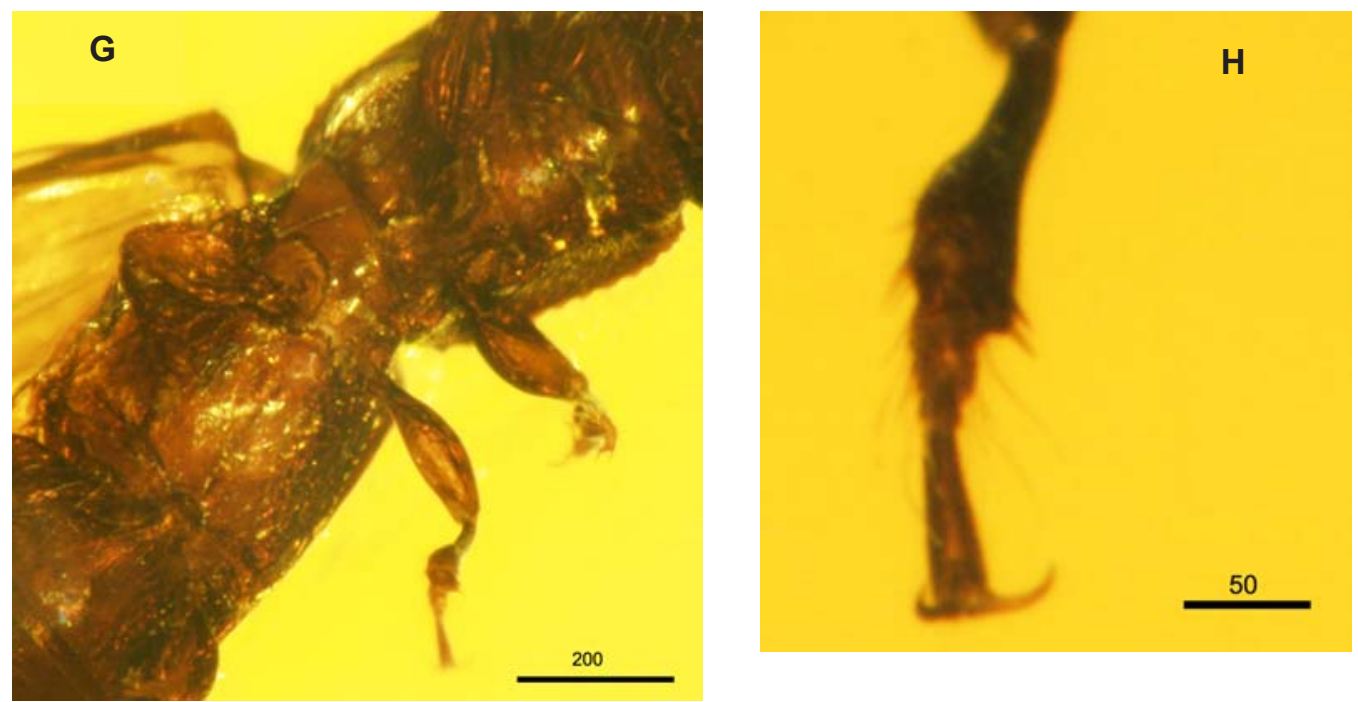

Рис. 1. Europs makarovi sp.n., фото (масштабные линейки в мкм).

А - общий вид, дорзально; В - голова спереди; C - голова и переднеспинка, дорзально; D - усик, вентрально; Е - общий вид, вентрально; F - голова и переднеспинка, вентрально; G - переднее, средне- и заднегрудь, вентрально; Н — средняя лапка; I - брюшко, вентрально.

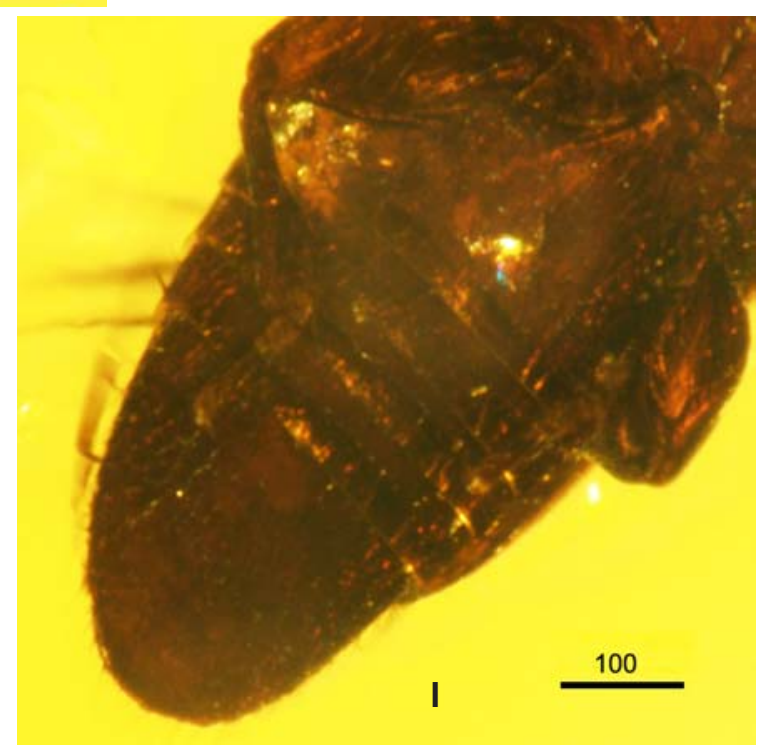

\section{Taxonomical part}

Monotomidae Laporte, 1840

Monotominae Laporte, 1840

Europini Sen Gupta, 1988

Europs Wollaston, 1854

\section{Europs makarovi sp.n.}

Figs. 1, 2.

HOLOTYPE. The specimen(UCP No. 1014) is from Mexican amber (Simojovel), Miocene.
Possibly male (because elytra expose 2 abdominal segments, tarsi 554).

DESCRIPTION. Body elongate, flattened, glabrous (Fig. 1A). Body length $=1.8 \mathrm{~mm}, \mathrm{LP}=$ $0.42, \mathrm{WP}=0.43 \mathrm{~mm}, \mathrm{WH}=0.39 \mathrm{~mm}, \mathrm{LE}=0.83$ $\mathrm{mm}$; pygidial length $0.24 \mathrm{~mm}$ (pygidial length/ width ratio 0.79). Colouration uniformly dark brown. Pubescence: setae on the upper surface of the body indistinct at 96x; tarsi and antennae with fine pubescence.

Head prognathous, long $\mathrm{WH} / \mathrm{WP}=0.9$; the front very coarsely and densely punctate (Fig. 
1B), the puncturation on the frons is slightly finer than on the pronotum. Head long, 0.8 times as long as broad; ratio of head length to length of pronotum is 0.76 . Head with moderately large and dense punctures ventrally. The area between the eyes has a flat depression. Eyes convex, large and prominent, finely facetted. Frons without subtriangular depression. Antennae short, extending to the anterior one-fourth of the pronotum; 11-segment with 3-segment antennal club (the club seems to be 2-segment because of the fused antennomeres X and XI); scape large, broader than any segments II-VIII, 1.8 times longer than the pedicel; antennomere II suboval, 1.5 times longer than antennomere III; antennomere III longer than any of the antennomeres IV-VIII, antennomeres III-VIII nearly equal in length and width; antennomere IX transverse, 1.8 times wider than long, as wide as antennomere X (Fig. 1D). Temples short, with a length of about 0.6 times the longitudinal diameter of the eyes, truncate. Neck distinct. Antennal grooves absent.

Pronotum weakly elongate $(\mathrm{LP} / \mathrm{WP}=0.97)$; maximal width in anterior one-fourth, slightly narrowed anteriad and posteriad; lateral margins not furrowed, parallel; the pronotal disc weakly convex; anterior and posterior margins straight; lateral sides crenulated; anterior angles angulated, not protruding; posterior angles strongly rounded; pronotal puncturation round, irregular, coarse and dense on the disc and on the sides, moderately large (punctures on the pronotal disc distinctly larger than elytral punctures in the basal half), distance between punctures varying from 0.5 to 1 times the diameter of a single puncture; microsculpture indistinct. Pronotal disc rather flat; about the same width in the anterior and posterior halves; with grooves, forming a lyre figure (Figs 1C, 2). The smooth, longitudinal, medial impunctate area between grooves is wide (as wide as diameters of 7-8 punctures). Transversal impression in front of the base of pronotum present.

Prothorax weakly convex, with small and very sparse punctures, shagreened. Protrochantins partially exposed. Procoxae rounded, procoxal cavities broadly closed externally.
Prosternal process large, trapezoidal, distinctly widened posteriorly; covered with small, sparse punctures, posterior margin convex, length nearly 1.7 times of the transverse diameter of the procoxa. Width of the neck of the prosternal process equal to half the diameter of procoxae. Length of the prothorax equal to the length of the metathorax (Fig. 1E). Meso- and metaventrites with distinctly denser and larger puncturation than the prosternum; shagreened between punctures. Posterior margin of metaventrite straight with a narrow excision medially (between metacoxae). Mesocoxae short-oval (Fig. $1 \mathrm{~F})$, the distance between them nearly equal to 0.5 times the transverse diameter of the mesocoxa. The metasternal process extends to the mesocoxa (Fig. 1G). Longitudinal medial line present. Metacoxae elongate-oval. Metacoxal lines present, angulated.

Elytra bare (without visible accumbent setae at 300x), each with rows of punctures forming striae, relatively long $(\mathrm{LE} / \mathrm{LP}=1.98)$, widest just before the middle, truncated at the apex, exposing two abdominal tergite, with the base distinctly wider than the base of the pronotum. Elytral punctures, round, small (punctures in basal one-third slightly larger than at the apex), arranged in regular striae; with fine, very short erect setae; the distance between punctures equal to 2-3 times the diameter of one puncture; striae distinct throughout entire length of elytron; intervals flat, shagreened. Elytral pubesence very short, arranged in rows. Inflexed part of elytron with three striae of punctures. Elytra with sutural lines. Hind wings present. Scutellum triangular, impunctate, and without setae.

Abdomen with 5 segments, ventrites I and V elongate, II-IV comparatively short, subequal, last visible sternite without modifications, sparsely and finely punctured, covered by setae. Abdominal process between the hind coxae triangular, with a rounded apex. First visible abdominal sternite with angulated postcoxal lines. First ventrite without medial setigerous plaque. Ventrite 1 elongate, longest, distinctly longer than ventrites II-V combined. Ventrites II-IV short, equal in length. Ventrite V simple, with a widely rounded posterior margin. Rela- 


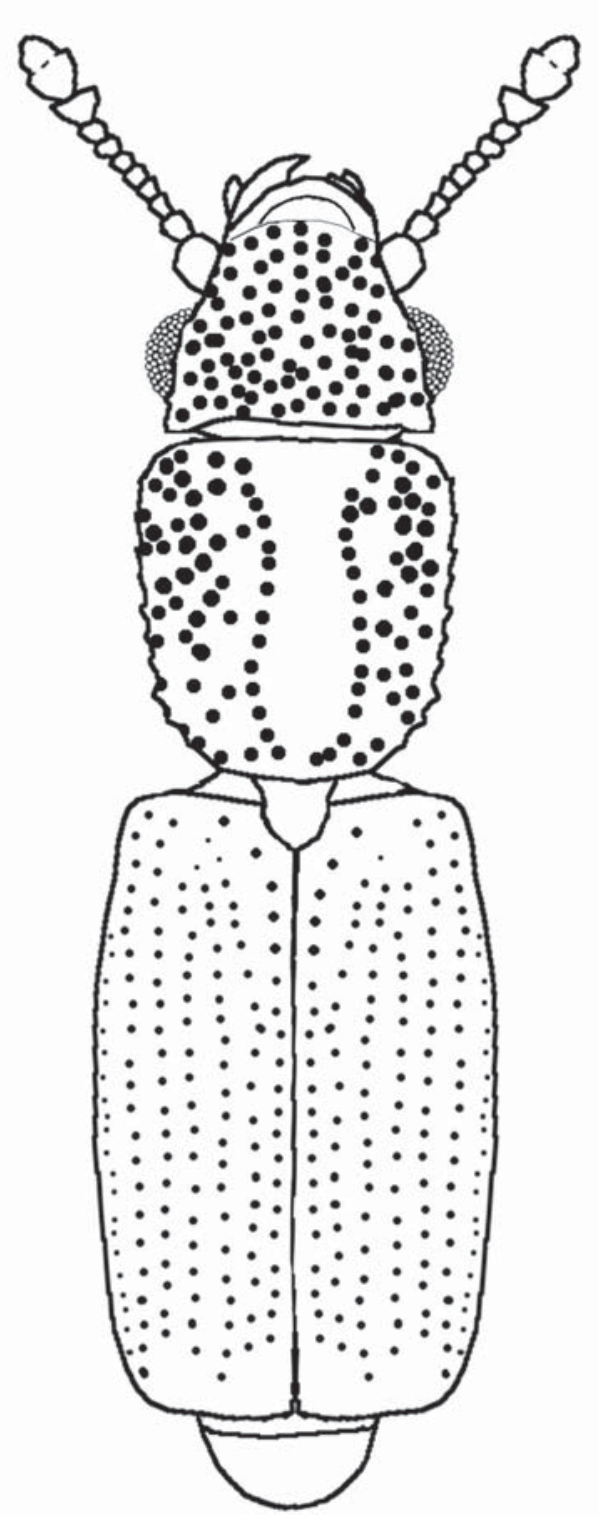

Fig. 2. Europs makarovi sp.n.

Total view, dorsal, line drawings.

Рис. 2. Europs makarovi sp.n.

Общий вид, дорзально.

tive length ratios of ventrites $\mathrm{I}-\mathrm{V}$ equal to 49:11:10:11:45. Two visible tergites covered with fine and dense punctures; with a widely rounded apex (Fig. 1I).

Legs relatively short and robust. Femur spindle-shaped, distinctly widened medially. Femo- ra wide; tibiae slightly curved. Tibia gradually widened apically; about 0.75 times the length of the femur, with two short apical spurs (Fig. 1H). Legs with tarsal formula 5-5-4. Penultimate tarsomere not bilobed; ultimate tarsomere distinctly longer than all previous tarsomeres combined. Claws simple, long and thin.

ETYMOLOGY. Patronym is dedicated for prominent coleopterist Prof. Kirill V. Makarov (Moscow Pedagogical State University).

\section{Discussion}

The new species of Europs are distinguished from all contemporary species of the genus by a combination of features: uniformly dark body colour; relatively long head (ratio of head length to length of pronotum is 0.76 ); head puncturation very coarse; pronotum with parallel sides; disc of pronotum with 2 longitudinal, more or less parallel, punctate grooves, forming a lyre figure; impunctate medial area between grooves is wide (as wide as the diameters of 7-8 punctures); not rounded but triangularly produced coxal line in the first ventrite; elytra proportionally longer ( $\mathrm{LE} / \mathrm{LP}>1.98)$. The relatively long head, which does not completely correspond to the etymology of Europs (from عúpús/ eurys "wide" and $\omega \psi /$ ops "face"), is mentioned in the title. The Mexican species, e.g. Europs convergens Sharp, 1900, E. diffusus Sharp, 1900; E. fervidus; E. germari Reitter, 1876; E. luridipennis (Reitter, 1876); E. obtusus Sharp, 1900; E. rhizophagoides Reitter, 1872, are distinguished by the same features; Guatemalan species $E$. cognatus Sharp, 1900; E. discedens Sharp, 1900; E. longulus Sharp, 1900; E. nanus Sharp, 1900; E. oxytela Sharp, 1900, not known from Mexico, differ in the same way.

In addition to the above general difference between the new species and the others, additional differences from the Mexican and Guatemalan species can be indicated (Sharp, 1900). $E$. diffusus, E. discedens, E. fervidus, and E. rhizophagoides (as well as E. maculatus Grouvelle, 1896) clearly differ from the new species by the absence of a distinct lyre-shaped figure on the pronotum. E. obtusus has an ambiguous 
lyre-shaped figure on the pronotum, but the size is larger: $2.2 \mathrm{~mm}$. E. oxytela has a short wide head, fine puncturation of the head and pronotum, pronotum much more narrowed posteriorly, and also a large body size: $2.5 \mathrm{~mm}(1.8 \mathrm{~mm}$ for E. makarovi). E. nanus has a short wide head, fine puncturation of the head and pronotum, without a clear lyre-shaped figure on the pronotum, and also a small body size: $1.5 \mathrm{~mm}$. $E$. convergens and E. longulus already differ because of the large body size: $3.5 \mathrm{~mm}$ ( $E$. convergens) and $3 \mathrm{~mm}$ (E. longulus). E. luridipennis has a short wide head, and also a large body size: $3 \mathrm{~mm}$.

The new species is very similar to Guatemalan Europs cognatus Sharp, 1900 and Californian E. sulcicollis Bousquet, 2003. The new species differs from E. cognatus and E. sulcicollis because of its relatively longer head, and much stronger puncturation of the head and pronotum. In E. cognatus, the points on the head are twice the diameter of the facet of the eye; in E. makarovi sp.n., three times as many. In addition, in E. cognatus, the head behind the eyes is parallel-sided, while in E. makarovi sp.n. it is somewhat enlarged. The new species is smaller than these species, $1.8 \mathrm{~mm}$ versus $2.5 \mathrm{~mm}$ in $E$. cognatus, and 1.9-2.6 $\mathrm{mm}$ in E.sulcicollis.

The E. makarovi sp.n. differs from E. insterburgensis by its relatively longer head (the ratio of head length to maximum width with the eyes of the new species is 0.8 , and for E. insterburgensis 0.7 ), more than half the length of the pronotum; much larger puncturation on the head and pronotum; pronotum with more parallel sides, narrowing just before the base; pronotum with impunctate section in the middle of the disc, limited by lines from large points located in longitudinal rows. These two lines are slightly curved basally and create a lyre figure. The impunctate area is broad, as wide as the diameters of 7-8 punctures; E. insterburgensis with impunctate area width 2 diameters of punctures. The scutellum is triangular; in E. insterburgensis with an oval scutellum. The representatives of the genus might further be recorded for the neotropical fauna of Miocene Dominican amber, that is coeval to Mexican amber (Poinar,
1992); the single identified species of the family recorded in the extant fauna of Hispaniola Island is E. maculata Grouvelle, 1896 (PerezGelabert, 2008).

Acknowledgements. The study was supported by the research project "Taxonomic and Biochorologic Analysis of the Animal Kingdom as the Basis for the Study and Preservation of the Structure of Biodiversity (AAAA-A16116021660077-3)," Zoological Museum of Moscow State University.

We would like to thank Krzysztof Bondaruk (Białystok) for help in preparing the piece of amber for research. We also thank Prof. Alexander Herczek (University of Silesia in Katowice) for verification of the Coccinea determination, and Dr. S.E. Chernyshov (Institute of Systematics and Ecology of Animals of Siberian Branch of Russian Academy of Sciences) for critical review the manuscript.

\section{References}

Alexeev V.I. 2014. Europs insterburgensis sp. nov., a new root-eating beetle from Baltic amber (Coleoptera: Monotomidae) // Genus. Vol.25. No.3. P.415-420.

Bousquet Y. 2003. Review of the genus Europs Wollaston (Coleoptera: Monotomidae) of America, north of Mexico // Pan-Pacific Entomol. Vol.79. No.1. P.11-22.

Bousquet Y. 2010. 10.8. Monotomidae Laporte 1840 // R.A.B. Leschen, R.G. Beutel (eds.). Handbook of zoology. Vol. 2: Morphology and systematics (Elateroidea, Bostrichiformia, Cucujiformia partim). Handbook of zoology, Arthropoda: Insecta. Berlin: Walter de Gruyter. P.319-324.

Bukejs A., Alexeev V.I. 2015. Description of the second fossil Baltic amber species of Monotomidae (Coleoptera: Cucujoidea) // Zootaxa. Vol.3946. No.3. P.445-450.

Cai Chen-Yang, Ślipiński A., Huang Di-Ying. 2015. The oldest root-eating beetle from the Middle Jurassic of China (Coleoptera, Monotomidae) // Alcheringa: An Australasian Journal of Palaeontology. Vol.39. No.4. P.488-493.

Jelínek J. 2007. Monotomidae // I. Löbl, A. Smetana (eds.). Catalogue of Palaearctic Coleoptera, Vol.4. Stenstrup: Apollo Books. P.491-495.

Jenkins D.A., Cline A.R., Irish B., Goenaga R. 2013. Attraction of pollinators to atemoya (Magnoliales: Annonaceae) in Puerto Rico: A synergistic approach using multiple nitidulid lures // Journal of Economic Entomology. Vol.106. No.1. P.305-310. DOI: http:// dx.doi.org/10.1603/ec12316. 
Jenkins D.A., Millan-Hernandez C., Cline A.R., McElrath T.C., Irish B., Goenaga R. 2015. Attraction of pollinators to atemoya (Annona squamosa $\mathrm{x}$ Annona cherimola) in Puerto Rico // Journal of Economic Entomology. Vol.108. No.4. P.1923-1929. DOI: http://dx.doi. org/10.1093/jee/tov136.

Jiang R., Liu Z., Wang S. 2019. Fossil evidence for sexual dimorphism in Monotomidae beetles from mid-Cretaceous Burmese amber// Cretaceous Research. Vol.102. P.7-11. https://doi.org/10.1016/j.cretres.2019.05.008

Kirejtshuk A.G., Azar D., Tafforeau P., Boistel R., Fernandez V. 2009. New beetles of Polyphaga (Coleoptera, Polyphaga) from Lower Cretaceous Lebanese amber // Denisia. Vol.26. P.119-130.

Kirejtshuk A.G., Azar D. 2013. Current knowledge of Coleoptera (Insecta) from the Lower Cretaceous Lebanese amber and taxonomical notes for some Mesozoic groups // Terrestrial Arthropod Reviews. Vol.6. No.1-2. P.103-134.

Kirejtshuk A.G., Nel A. 2013. Current knowledge of Coleoptera (Insecta) from the Lowermost Eocene Oise amber // Insect Systematics \& Evolution. Vol.44. P.175-201.

Liu Zhenhua, Tihelka E., McElrath T.C., Yamamoto Shûhei, Slipinski A., Wang Bo, Ren Dong, Pang Hong. 2020. New minute clubbed beetles (Coleoptera, Monotomidae, Lenacini) from mid-Cretaceous amber of Northern Myanmar // Cretaceous Research. Vol.107 https://doi.org/10.1016/j.cretres.2019.104255

McElrath T., Bousquet Y., McHugh J.V. 2012. Monotomidae. Root-eating beetles. Version 06 December
2012 (temporary). http://tolweb.org/Monotomidae/ 9147/2012.12.06 in The Tree of LifeWeb Project, http://tolweb.org/. Accessed 23 Sept 2014.

Perez-Gelabert D.E. 2008. Arthropods of Hispaniola (Dominican Republic and Haiti): A checklist and bibliography // Zootaxa. Vol.1831. P.1-530.

Peris D., Delclos X. 2015. Fossil Monotomidae (Coleoptera: Polyphaga) from Laurasian Cretaceous amber // Organisms, Diversity and Evolution. Vol.15. No.2. P.333-342.

Peris D., Ruzzier E., Perrichot V., Delclòs X. 2016. Evolutionary and paleobiological implications of Coleoptera (Insecta) from Tethyan-influenced Cretaceous ambers // Geoscience Frontiers. Vol.7. No.4. P.695-706.

Poinar G.O. 1992. Life in Amber. Stanford University Press. 350 pp.

Sen Gupta T. 1988. Review of the genera of the family Rhizophagidae (Clavicornea: Coleoptera) of the world // Memoirs of the Zoological Survey of India. Vol.17. P. $1-58$

Sharp D. 1900. Monotomidae // F.D. Godman, O. Salvin (eds.). Biologia Centrali-Americana. Insecta, Coleoptera. II. Part 1. London: Dulau and Co. P.563579.

Solórzano-Kraemer M.M. 2010. Mexican Amber // D. Penney (ed.). Biodiversity of fossils in amber from the major world deposits. Manchester, UK: Siri Scientific Press. P.42-56.

Responsible editor K.G. Mikhailov 